\title{
Interleukin-6 promotes tumor progression in colitis-associated colorectal cancer through HIF-1 $\alpha$ regulation
}

\author{
JUN HAN $^{1 *}$, QIULEI XI ${ }^{1 *}$, QINGYANG MENG ${ }^{1}$, JINGZHENG LIU $^{2}$, YONGXIAN ZHANG $^{3}$, \\ YUSONG HAN $^{1}$, QIULIN ZHUANG ${ }^{1}$, YI JIANG ${ }^{1}$, QIURONG DING ${ }^{3}$ and GUOHAO WU ${ }^{1}$ \\ ${ }^{1}$ Department of General Surgery; ${ }^{2}$ Endoscopy Center and Endoscopy Research Institute, \\ Zhongshan Hospital, Fudan University, Shanghai 200032; ${ }^{3}$ Institute for Nutritional Sciences, \\ Shanghai Institutes for Biological Sciences, Chinese Academy of Sciences, Shanghai 200031, P.R. China
}

Received July 16, 2015; Accepted September 1, 2016

DOI: $10.3892 / 01.2016 .5227$

\begin{abstract}
Interleukin-6 (IL-6) is a well-known etiological factor of colitis-associated colorectal cancer (CAC) and has a significant role in CAC progression. In addition, hypoxia-inducible factor $1 \alpha(\mathrm{HIF}-1 \alpha)$ serves a primary role in the progression of CAC. However, the association between IL- 6 and HIF-1 $\alpha$ during the progression of CAC remains unclear. To investigate this association, the present study induced CAC in a mouse model using azoxymethane and dextran sulfate sodium. In addition, an anti-IL-6 receptor antibody was used to inhibit IL-6. In this model, anti-IL-6 receptor antibody treatment significantly inhibited the development of CAC and the expression of HIF-1 $\alpha$, in colorectal adenomas and adenocarcinomas. In patients with CAC, the HIF-1 $\alpha$ gene was demonstrated to be overexpressed in tumor tissue compared with adjacent non-malignant tissue. Furthermore, HIF-1 $\alpha$ mRNA expression was positively correlated with serum IL-6 concentration. The results of the present study suggest that IL- 6 promotes CAC progression, in the early stage of the disease, through HIF-1 $\alpha$ regulation.
\end{abstract}

\section{Introduction}

Colitis-associated colorectal cancer (CAC) is a subtype of colorectal cancer that is associated with inflammatory bowel diseases (IBD), including ulcerative colitis (UC) and Crohn's disease (1). Over $20 \%$ of patients with IBD develop CAC within 30 years of the disease onset and $>50 \%$ of these will succumb to $\mathrm{CAC}$ (2). The primary risk factors for CAC progression

Correspondence to: Professor Guohao Wu, Department of General Surgery, Zhongshan Hospital, Fudan University, 180 Fenglin Road, Shanghai 200032, P.R. China

E-mail: profwugh@163.com

*Contributed equally

Key words: colitis-associated colorectal cancer, interleukin-6, hypoxia-inducible factor $1 \alpha$, tumor progression, mouse, human are the duration and severity of intestinal inflammation (3). Increasing evidence supports the importance of pro-inflammatory cytokines in CAC progression (4-7). Interleukin-6 (IL-6), a pro-inflammatory cytokine, is a key regulator in the development of CAC (8). A previous study demonstrated that IL-6 is overexpressed in patients with active UC and CAC (9). However, despite evidence implicating the importance of IL-6 in the progression of CAC, the underlying molecular mechanisms of this association remain unclear.

Hypoxia is a common feature of solid tumors, including $\mathrm{CAC}$, to which tumor cells frequentlyadapt through changes in their gene expression patterns (10). Hypoxia-inducible factor $1 \alpha(\mathrm{HIF}-1 \alpha)$, an inducible transcription factor, is typically considered to be the primary regulator of the hypoxic adaptive response (10) and is regulated by the partial pressure of oxygen (11). In addition, a number of growth factors, including human epidermal growth factor receptor-2 and insulin-like growth factor-2, and cytokines, including tumor necrosis factor- $\alpha$, have been demonstrated to regulate the expression of HIF-1 $\alpha$ (12-14). Furthermore, previous studies identified that the activation of oncogenes and loss of function of tumor suppressor genes effects HIF-1 $\alpha$ expression $(15,16)$. HIF-1 $\alpha$ induces the expression of hundreds of genes and serves important roles in various aspects of cancer biology, including angiogenesis, invasion and metastasis (17-19). In clinical studies, HIF-1 $\alpha$ was shown to be overexpressed in multiple types of cancer, including colorectal $(20,21)$. In addition, HIF-1 $\alpha$ was identified to be overexpressed in patients with IBD and in the early stages of colorectal cancer (22). Furthermore, patients carrying one or both of the common HIF-1 $\alpha$ polymorphisms, C1772T and G1790A, displayed a significantly higher risk for the development of CAC (23). These results indicate that HIF-1 $\alpha$ serves a significant role in the progression of CAC. However, the association between IL- 6 and HIF-1 $\alpha$ during the progression of $\mathrm{CAC}$ remains unclear.

In the present study, the association between IL-6 and HIF- $1 \alpha$ in the development of CAC was investigated. The results of the current study demonstrated that, in a CAC mouse model, theanti-IL-6 receptor antibody used inhibited the progression of CAC and decreased the expression of HIF-1 $\alpha$. Further analysis in human samples revealed that the serum concentration of IL- 6 was positively correlated with HIF-1 $\alpha$ 
mRNA expression in CAC tumor tissues. In conclusion, the results of the present study indicate that IL-6 promotes CAC progression through the regulation of HIF-1 $\alpha$.

\section{Materials and methods}

Mouse CAC model. Male BALB/c mice (6-8 weeks old; $18.3 \pm 1.4 \mathrm{~g}$ ), purchased from the Shanghai Laboratory Animal Center (Shanghai Institutes for Biological Sciences, Chinese Academy of Sciences, Shanghai, China), were used to produce the CAC model. Mice were housed at $22 \pm 1^{\circ} \mathrm{C}$, with a $12 \mathrm{~h}$ light/dark cycle, and ad libitum access to food and water. Mice were divided into two groups; the immunoglobulin G $(\mathrm{IgG})$ group (control group, $\mathrm{n}=8$ ) and the anti-IL-6 receptor antibody (both eBioscience, Inc., San Diego, CA, USA) group (treatment group, $n=8$ ). The protocol to induce CAC in a mouse model was performed as previously described by Neufert et al (24). Briefly, mice were peritoneally injected with azoxymethane (AOM, 10 mg/kg; Sigma-Aldrich; Merck Millipore, Darmstadt, Germany) at the beginning of the first week. Then, mice were given drinking water supplemented with $2 \%$ (w/v) dextran sulfate sodium (DSS; Sigma-Aldrich; Merck Millipore) for 1 week, followed by water alone for 2 weeks, this was repeated 3 times (Fig. 1A). Simultaneously, mice in the treatment and control groups were injected peritoneally every 2 days with $10 \mu \mathrm{g}$ anti-IL-6 receptor antibody or $10 \mu \mathrm{g}$ $\mathrm{IgG}$, respectively, diluted in $200 \mu \mathrm{l}$ normal saline.

The mice were sacrificed via cervical dislocation at the end of week 9. Subsequently, large intestines (from the ileocecal junction to the anal verge) were collected, longitudinally cut open along the main axis and washed with normal saline. Visible neoplasms were counted and collected, the length and width of each neoplasm was measured using a digital micro ruler, and the neoplasm area was calculated by multiplying the length and width. Subsequently, neoplasms were cut into halves, where 1 half was prepared for histopathological analysis and immunohistochemistry, and the other half was prepared for reverse transcription-quantitative polymerase chain reaction (RT-qPCR) analysis and western blotting. All procedures were carried out in accordance with the guidelines and regulations for the Use of Experimental Animals by the Chinese Academy of Sciences (Beijing, China). The current study was approved by the Animal Ethics Committee of Zhongshan Hospital of Fudan University (Shanghai, China).

Collection of patient samples. A total of 13 patients (males $\mathrm{n}=8$, females $n=5$ ), aged between 41 and 76 years old ( $58.6 \pm 10.9$ years), diagnosed with CAC and receiving surgical treatment at Zhongshan Hospital of Fudan University between June 2012 and December 2014 were included in the present study. Tumor tissue and adjacent non-malignant tissue was collected during surgery and stored at $-80^{\circ} \mathrm{C}$ until required for further analysis. A total of $5 \mathrm{ml}$ blood was collected from each patient prior to surgery and immediately centrifuged at 2,400 $\mathrm{x} g$ for $10 \mathrm{~min}$ at room temperature. The serum obtained was preserved at $-80^{\circ} \mathrm{C}$ until required. The patients included in the present study had not received chemotherapy or radiotherapy prior to surgery. Informed consent was obtained from all participants included in the current study and ethical permission for the study was obtained from the Zhongshan Hospital of Fudan University.
Histopathological analysis. Biopsy specimens were fixed with $10 \%$ formalin, embedded in paraffin and cut into $4-\mu \mathrm{m}$-thick sections. Hematoxylin and eosin staining was performed on the sections to distinguish between colorectal adenomas and adenocarcinomas. All results were confirmed by 2 pathologists.

Measurement of serum IL-6 concentration. The serum concentration of IL-6 was assessed using Canine IL-6 DuoSet ELISA (R\&D Systems, Inc., Minneapolis, MN, USA; cat. no. DY1609), according to the manufacturer's protocol. The detection range of this kit was between 0.156 and $10.0 \mathrm{pg} / \mathrm{ml}$, with a sensitivity of $0.11 \mathrm{pg} / \mathrm{ml}$.

Immunohistochemistry. Immunohistochemical staining of colorectal tissue sections was performed as previously described by Yuan et al (25). Briefly, tissue sections were treated with xylene and a series of graded alcohols. Antigen retrieval was performed with $0.01 \mathrm{M}$ citrate buffer $(\mathrm{pH}$ 6.0) at $95^{\circ} \mathrm{C}$ for $20 \mathrm{~min}$. Following antigen retrieval, the sections were incubated with primary mouse monoclonal anti-HIF-1 $\alpha$ antibody (1:100; Abcam, Cambridge, UK; cat. no. ab113642) at $4^{\circ} \mathrm{C}$ for $12 \mathrm{~h}$. Following three washes with $0.01 \mathrm{mmol} / 1$ PBS, sections were incubated with goat anti-mouse IgG H\&L (FITC) biotinylated secondary antibody (1:50; Abcam; cat. no. ab6785) at $37^{\circ} \mathrm{C}$ for $1 \mathrm{~h}$ and horseradish peroxidase-conjugated streptavidin (1:10,000; Abcam; cat no. ab7403) for at room temperature $15 \mathrm{~min}$. Then, sections were treated with diaminobenzidine and hydrogen peroxide chromogen substrate plus diaminobenzidine enhancer for $10 \mathrm{~min}$, followed by counter staining with Mayer's hematoxylin. The percentage and intensity of stained immunoassayed cells was evaluated over 5 visual fields, selected at random, at a magnification of $\mathrm{x} 400$ using a light microscope. The degree of staining was evaluated independently by 2 pathologists. Expression of HIF-1 $\alpha$ was indicated by the presence of cytoplasmic and/or membranous staining.

Total RNA extraction and RT-qPCR analysis. Total RNA was isolated from human and mouse colorectal tissue samples using the RNAprep Pure Tissue Kit (Tiangen Biotech Co., Ltd., Beijing, China; cat. no. DP431) and cDNA was synthesized from $1 \mu \mathrm{g}$ total RNA using the cDNA Synthesis Kit (Takara Bio, Inc., Otsu, Japan; cat. no. 6130), following the manufacturer's protocol. RT-qPCR reactions were performed using the SYBR Premix Ex Taq kit (Takara Bio, Inc.; cat no. DRR820A) on the StepOnePlus Real-Time PCR System (Applied Biosystems; Thermo Fisher Scientific, Inc., Waltham, MA, USA). Thermocycling conditions were as follows: $95^{\circ} \mathrm{C}$ for $2 \mathrm{~min} ; 40$ cycles of $30 \mathrm{sec}$ at $95^{\circ} \mathrm{C} ; 10 \mathrm{sec}$ at $60^{\circ} \mathrm{C} ; 30 \mathrm{sec}$ at $72^{\circ} \mathrm{C}$; and $10 \mathrm{~min}$ at $72^{\circ} \mathrm{C}$. The expression level of the HIF- $1 \alpha$ gene relative to $\beta$-actin was determined using the SYBR Green-based comparative CT method $\left(2^{-\Delta \Delta C q}\right)(26)$. The primer sequences used were as follows: Human HIF-1 $\alpha$ sense, 5'-ACT TCTGGATGCTGGTGATT-3' and antisense, 5'- GTCGTG CTGAATAATACCACT-3'; mouse HIF-1 $\alpha$ sense, 5 '-AGCCCT AGATGGCTTTGTGA-3' and antisense, 5'-TATCGAGGC TGTGTCGACTG-3'; and human and mouse $\beta$-actin sense, 5'- CACGATGGAGGGGCCGGACTCATC-3' and antisense, 5'-TAAAGACCTCTATGCCAACACAGT-3'. 
Western blotting. Preparation of total protein lysates and western blot analysis was performed as previously described by Yuan et al (25). To detect HIF-1 $\alpha$, monoclonal anti-HIF-1 $\alpha$ antibody $(1: 1,000)$ was used. Tubulin expression, detected using an anti-tubulin antibody (1:2,000; Sigma-Aldrich; Merck Millipore) was used as an endogenous control.

Statistical analysis. Results are presented as the mean \pm standard error of the mean. Data from the present study was analyzed with GraphPad Prism (version 5.0; GraphPad Software, Inc., La Jolla, CA, USA) using a Student's $t$-test. The correlation between serum IL- 6 concentration and HIF-1 $\alpha$ mRNA expression was analyzed using the Pearson product-momentum correlation coefficient. $\mathrm{P}<0.05$ was considered to indicate a statistically significant difference.

\section{Results}

Anti-IL-6 receptor antibody inhibits the development of CAC. CAC was successfully induced in the mice using AOM and DSS (Fig. 1A). Macroscopically, the majority of colorectal neoplasms were located in the middle and distal colon (Fig. 1B). Mice in the treatment group developed significantly fewer and smaller neoplasms compared with mice in the control group $(\mathrm{P}<0.05$; Fig. 1C and D). Following histopathological examination, colorectal neoplasms were divided into adenomas and adenocarcinomas (Fig. 1E). The incidence of colorectal adenocarcinomas was $87.5 \%$ (7/8 mice) in the treatment group and $100 \%$ (8/8 mice) in the control group, while the incidence of colorectal adenomas was $100 \%$ (8/8 mice) in the treatment and control groups. These results suggest that the anti-IL-6 receptor antibody used inhibits the development of CAC.

Anti-IL-6 receptor antibody downregulates $H I F-1 \alpha$ in colorectal adenocarcinomas. To identify the potential mechanisms by which the anti-IL-6 receptor antibody inhibits the development of CAC and to investigate whether this effect is through the regulation of HIF-1 $\alpha$, the expression of HIF- $1 \alpha$ in colorectal adenocarcinomas was examined. RT-qPCR analysis demonstrated that HIF- $1 \alpha$ mRNA expression was significantly downregulated in colorectal adenocarcinomas following treatment with the anti-IL- 6 receptor antibody $(\mathrm{P}<0.05$ vs. control; Fig. 2A). In addition, western blotting identified a corresponding downregulation of HIF-1 $\alpha$ protein levels (Fig. 2B). Furthermore, immunohistochemistry revealed a notable decrease in HIF-1 $\alpha$ protein levels in the treatment group compared with the control group (Fig. 2C).

Anti-IL-6 receptor antibody downregulates $H I F-1 \alpha$ in colorectal adenomas. To investigate whether the anti-IL-6 receptor antibody used downregulates HIF-1 $\alpha$ in early stage $\mathrm{CAC}$, the expression of HIF-1 $\alpha$ in colorectal adenomas was examined. Similarly to the results observed in colorectal adenocarcinomas, HIF-1 $\alpha$ was found to be downregulated in colorectal adenomas following treatment with the anti-IL-6 receptor antibody (Fig. 3A-C). This indicates that IL-6 regulates HIF-1 $\alpha$ expression in early stage CAC.

$H I F-1 \alpha$ mRNA expression positively correlates with serum IL-6 concentration in patients with CAC. As HIF-1 $\alpha$

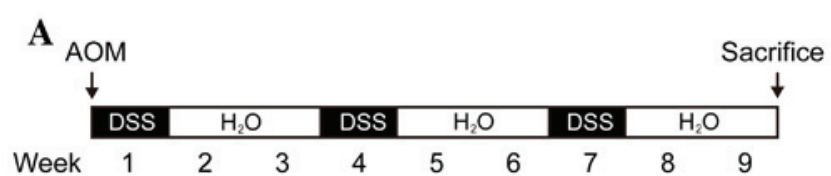

B

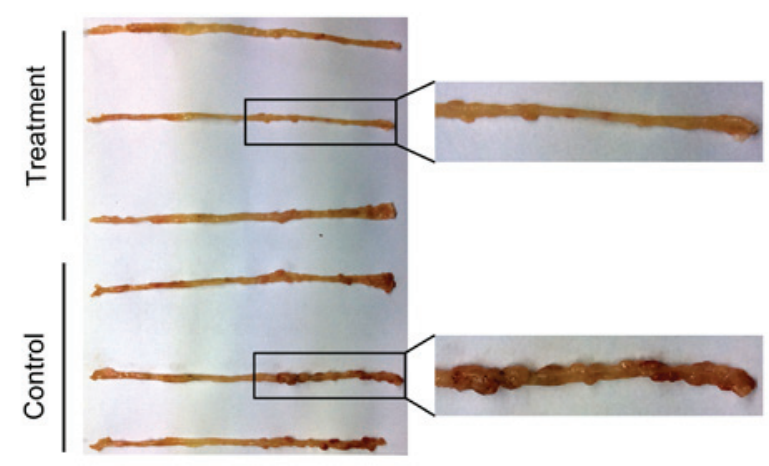

C

D
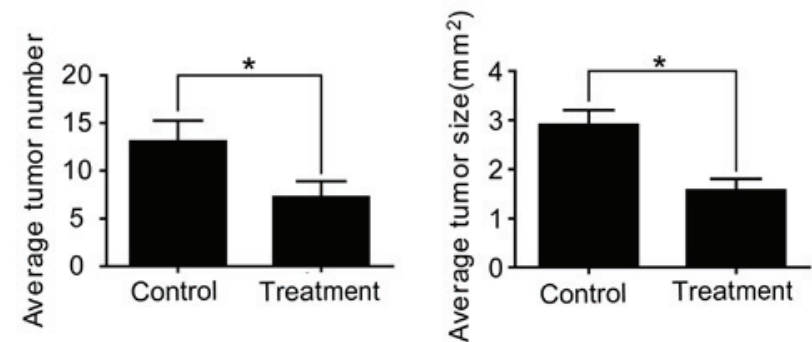

$\mathbf{E}$

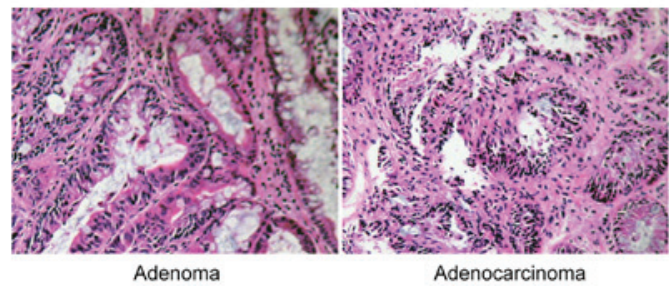

Figure 1. Anti-IL-6 receptor antibody inhibits the development of CAC (A) Schematic overview of CAC induction with AOM and DSS. Mice were peritoneally injected with $\mathrm{AOM}(10 \mathrm{mg} / \mathrm{kg})$ at the beginning of the first week. Subsequently, mice were treated with $2 \%$ DSS supplemented into their drinking water for 1 week, followed by 2 weeks of water alone. This cycle was repeated 3 times. In addition, anti-IL-6 receptor antibody and immunoglobulin $\mathrm{G}$ were peritoneally injected into treatment and control mice, respectively, every 2 days. (B) Macroscopic observation showed that the majority of colorectal neoplasms were located in the middle and distal colon. (C) Fewer and (D) smaller macroscopic neoplasms were observed in the treatment group compared with the control group. " $\mathrm{P}<0.05$. (E) Colorectal neoplasms were divided into adenomas and adenocarcinomas following histopathological examination (magnification, x200). IL-6, interleukin-6; CAC, colitis-associated colorectal cancer; AOM, azoxymethane; DSS, dextran sulfate sodium

expression was significantly downregulated by the anti-IL-6 receptor antibody used in the mouse CAC model, HIF-1 $\alpha$ expression was analyzed in patients with CAC to determine whether it positively correlated with serum IL-6 concentration. RT-qPCR analysis revealed that HIF-1 $\alpha$ mRNA levels were significantly increased in CAC tumor tissues compared with adjacent non-malignant tissues ( $\mathrm{P}<0.05$; Fig. 4A). The fold change in HIF- $1 \alpha$ mRNA expression in tumor tissues compared with adjacent non-malignant tissues was between 0.8 and 5.2 (median, 2.1). In addition, western blotting confirmed 
A

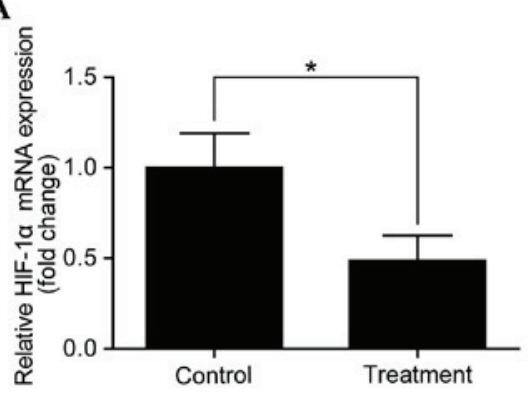

B

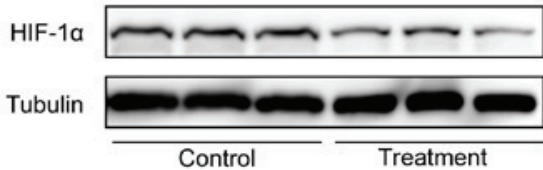

C

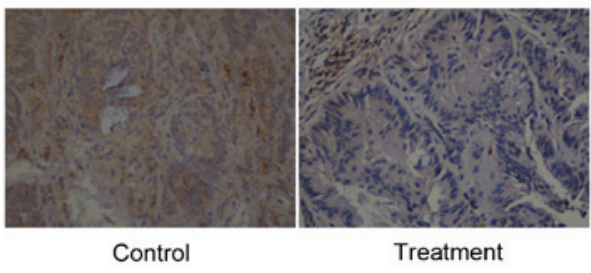

Figure 2. Anti-interleukin-6 receptor antibody downregulates HIF-1 $\alpha$ in colorectal adenocarcinomas. (A) Reverse transcription-quantitative polymerase chain reaction analysis showed that HIF- $1 \alpha$ mRNA expression was significantly downregulated in the treatment group compared with the control group. "P $<0.05$. (B) Western blot analysis and (C) immunohistochemistry (magnification, $\mathrm{x} 400$ ) demonstrated the downregulation of HIF-1 $\alpha$ protein levels in the treated group compared with the control group. HIF-1 $\alpha$, hypoxia-inducible factor $1 \alpha$.

A

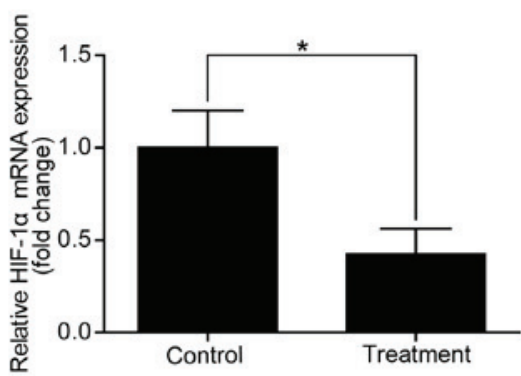

B

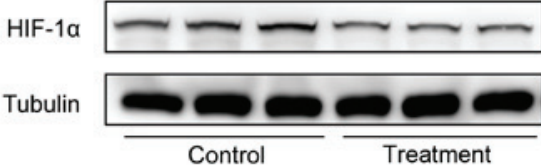

C

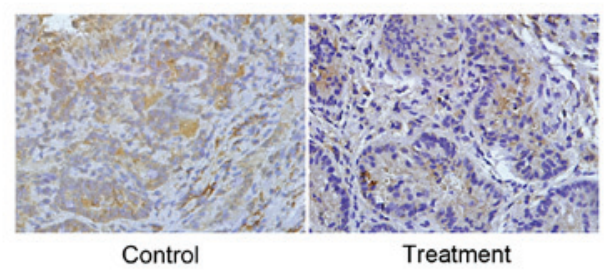

Figure 3. Anti-interleukin-6 receptor antibody downregulates HIF-1 $\alpha$ in colorectal adenomas. (A) Reverse transcription-quantitative polymerase chain reaction analysis showed that HIF- $1 \alpha$ mRNA expression was significantly downregulated in the treatment group compared with the control group. "P $<0.05$. (B) Western blot analysis and (C) immunohistochemistry (magnification, $\mathrm{x} 400$ ) demonstrated the downregulation of HIF-1 $\alpha$ protein levels in the treated group compared with the control group. HIF-1 $\alpha$, hypoxia-inducible factor $1 \alpha$.

A

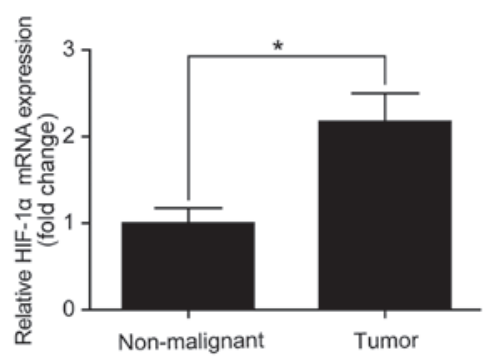

B

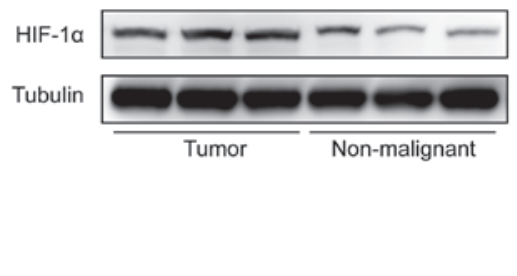

C

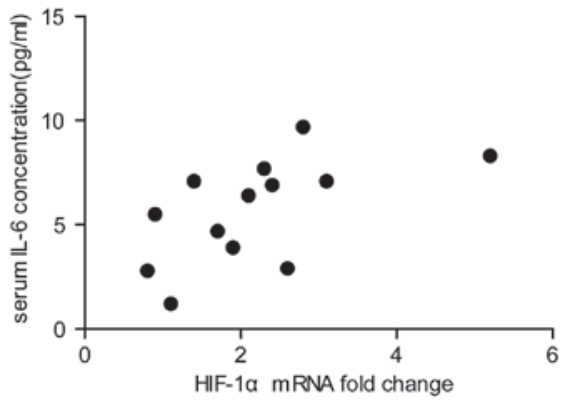

Figure 4. HIF-1 $\alpha$ mRNA expression positively correlates with serum IL-6 concentration in patients with CAC. (A) Reverse transcription-quantitative polymerase chain reaction analysis revealed that HIF-1 $\alpha$ mRNA was significantly overexpressed in tumor tissues compared with adjacent non-malignant tissues. ${ }^{*} \mathrm{P}<0.05$. (B) Western blot analysis demonstrated that the HIF-1 $\alpha$ protein was overexpressed in CAC tissue compared with adjacent non-malignant tissue. (C) The Pearson product-momentum correlation coefficient demonstrated that serum IL- 6 concentration was positively correlated with HIF-1 $\alpha$ mRNA expression in the tumor tissue of patients with $\mathrm{CAC}(\mathrm{r}=0.58 ; \mathrm{P}=0.04)$. HIF-1 $\alpha$, hypoxia-inducible factor $1 \alpha$; IL-6, interleukin- 6 ; CAC, colitis-associated colorectal cancer.

that there was an overexpression of HIF-1 $\alpha$ protein in the malignant tissues (Fig. 4B). Then, serum IL-6 concentration was examined in the participants, which identified that serum IL-6 concentrations were between 1.2 and $9.7 \mathrm{pg} / \mathrm{ml}$ (median, $6.4 \mathrm{pg} / \mathrm{ml}$ ). Furthermore, the Pearson product-momentum correlation coefficient showed that serum IL-6 concentration positively correlated with HIF- $1 \alpha$ mRNA expression in the tumor tissue of these patients with $\mathrm{CAC}(\mathrm{r}=0.58 ; \mathrm{P}=0.04$; Fig. 4C).

\section{Discussion}

IL-6 overexpression is a well-known risk factor for CAC and the role of HIF-1 $\alpha$ during CAC progression is well documented $(22,27)$. However, whether IL- 6 contributes to CAC progression through the regulation of HIF-1 $\alpha$ remains unclear. The results of the present study indicate that inhibition of IL-6 using an anti-IL- 6 receptor antibody hindered the development of CAC and decreased HIF-1 $\alpha$ expression, even in early stage 
CAC. In addition, HIF-1 $\alpha$ was demonstrated to be overexpressed in human CAC tumor tissue and positively correlated with serum IL- 6 concentration. These results indicate that IL- 6 promotes CAC progression by regulating HIF-1 $\alpha$ expression during the early stages of CAC development.

Following the combination of exposure to AOM and 3 cycles of DSS treatment, CAC was successfully induced in BALB/c mice. Similarly to a previous study (28), the tumor incidence rate was $100 \%$ in the mice. In addition, following the inhibition of IL-6 using the anti-IL-6 receptor antibody, tumor size and number was significantly reduced, which was consistent with the results of a previous study (29).

In recent years IL- 6 has emerged as a potential therapeutic target in patients diagnosed with malignant disease (30). For example, anti-IL-6 antibodies have been used to treat patients with multiple myeloma or acquired immune deficiency syndrome-associated Kaposi's sarcoma since the 1990s (31,32). In 2014 siltuximab, a chimeric anti-IL6 antibody, was approved by the U.S. Food and Drug Administration (FDA; Silver Spring, MD, USA) for the treatment of patients diagnosed with Castleman disease (33). In addition, siltuximab was used in clinical trials for a number of malignant tumors, including metastatic renal cell cancer, prostate cancer and colorectal cancer (34-36). Although tocilizumab, an anti-IL-6 receptor antibody, has not yet been approved for the treatment of malignant tumors, it has been approved by the FDA for the treatment of chronic inflammatory diseases, including rheumatoid arthritis and juvenile idiopathic arthritis (37). In the present study, the anti-IL- 6 receptor antibody used was observed to have a protective effect in a mouse CAC model. However, further investigations are required to validate the effectiveness of anti-IL-6 receptor antibody treatment of CAC.

Signal transducer and activator of transcription-3, suppressor of cytokine signaling-3 and vascular endothelial growth factor receptor- 2 were reported to be the downstream proteins through which IL-6 exerts its tumor promoting effect in CAC (38-41). However, there is little literature on the association between IL- 6 and HIF-1 $\alpha$ in the development of CAC. In the present study, HIF-1 $\alpha$ was downregulated in colorectal adenocarcinomas and adenomas in the mouse CAC model by the anti-IL- 6 receptor antibody, which indicates that IL-6 stimulates the development of CAC through the regulation of HIF-1 $\alpha$. However, whether IL-6 exerts its tumor promoting effect directly through the regulation of $\mathrm{HIF}-1 \alpha$ remains unclear.

In patients with CAC, HIF-1 $\alpha$ was overexpressed in tumor tissues compared with adjacent non-malignant tissues, which is consistent with the results of a previous study (18). In addition, a positive correlation between HIF- $1 \alpha$ mRNA expression and serum IL-6 concentration in patients with CAC was observed. However, these findings should be interpreted with caution due to the relatively small number of patients included in the present study. Further research with a larger sample size is required to confirm these results.

In conclusion, the present study provides evidence that IL-6 promotes the development of CAC through the regulation of HIF-1 $\alpha$ during the early stages of CAC progression. In addition, the results of the current study demonstrate that anti-IL-6 receptor antibodies are a potential therapeutic agent for CAC that warrant further investigation.

\section{Acknowledgements}

The present study was supported by the National Natural Science Foundation of China (grant no. 81372197).

\section{References}

1. Grivennikov SI: Inflammation and colorectal cancer: Colitis-associated neoplasia. Semin Immunopathol 35: 229-244, 2013.

2. Lakatos PL and Lakatos L: Risk for colorectal cancer in ulcerative colitis: Changes, causes and management strategies. World J Gastroenterol 14: 3937-3947, 2008.

3. Ullman TA and Itzkowitz SH: Intestinal inflammation and cancer. Gastroenterology 140: 1807-1816, 2011.

4. Waldner MJ and Neurath MF: Cytokines in colitis associated cancer: Potential drug targets? Inflamm Allergy Drug Targets 7: 187-194, 2008.

5. Dubois RN: Role of inflammation and inflammatory mediators in colorectal cancer. Trans Am Clin Climatol Assoc 125: 358-373, 2014.

6. Li Y, Deuring J, Peppelenbosch MP, Kuipers EJ, de Haar C and van der Woude CJ: IL-6-induced DNMT1 activity mediates SOCS3 promoter hypermethylation in ulcerative colitis-related colorectal cancer. Carcinogenesis 33: 1889-1896, 2012.

7. Qi H, Yang H, Xu G, Ren J, Hua W, Shi Y, Torsvik M, Florholmen J and Cui G: Therapeutic efficacy of IL-17A antibody injection in preventing the development of colitis associated carcinogenesis in mice. Immunobiology 220: 54-59, 2015.

8. Waldner MJ, Foersch S and Neurath MF: Interleukin-6-a key regulator of colorectal cancer development. Int J Biol Sci 8: 1248-1253, 2012.

9. Li Y, de Haar C, Chen M, Deuring J, Gerrits MM, Smits R, Xia B, Kuipers EJ and van der Woude CJ: Disease-related expression of the IL6/STAT3/SOCS3 signalling pathway in ulcerative colitis and ulcerative colitis-related carcinogenesis. Gut 59: 227-235, 2010.

10. Monti E and Gariboldi MB: HIF-1 as a target for cancer chemotherapy, chemosensitization and chemoprevention. Curr Mol Pharmacol 4: 62-77, 2011.

11. Wang GL, Jiang BH, Rue EA and Semenza GL: Hypoxia-inducible factor 1 is a basic-helix-loop-helix-PAS heterodimer regulated by cellular O2 tension. Proc Natl Acad Sci USA 92: 5510-5514, 1995.

12. Feldser D, Agani F, Iyer NV, Pak B, Ferreira G and Semenza GL: Reciprocal positive regulation of hypoxia-inducible factor 1alpha and insulin-like growth factor 2. Cancer Res 59: 3915-3918, 1999.

13. Laughner E, Taghavi P, Chiles K, Mahon PC and Semenza GL: HER2 (neu) signaling increases the rate of hypoxia-inducible factor 1alpha (HIF-1alpha) synthesis: Novel mechanism for HIF-1-mediated vascular endothelial growth factor expression. Mol Cell Biol 21: 3995-4004, 2001.

14. Hellwig-Bürgel T, Rutkowski K, Metzen E, Fandrey J and Jelkmann W: Interleukin-1beta and tumor necrosis factor-alpha stimulate DNA binding of hypoxia-inducible factor-1. Blood 94: 1561-1567, 1999.

15. Chen C, Pore N, Behrooz A, Ismail-Beigi F and Maity A: Regulation of glut1 mRNA by hypoxia-inducible factor-1. Interaction between H-ras and hypoxia. J Biol Chem 276: 9519-9525, 2001.

16. Zundel W, Schindler C, Haas-Kogan D, Koong A, Kaper F, Chen E, Gottschalk AR, Ryan HE, Johnson RS, Jefferson AB, et al: Loss of PTEN facilitates HIF-1-mediated gene expression. Genes Dev 14: 391-396, 2000.

17. Liao D and Johnson RS: Hypoxia: A key regulator of angiogenesis in cancer. Cancer Metastasis Rev 26: 281-290, 2007.

18. Semenza GL: Defining the role of hypoxia-inducible factor 1 in cancer biology and therapeutics. Oncogene 29: 625-634, 2010.

19. Pugh CW and Ratcliffe PJ: Regulation of angiogenesis by hypoxia: Role of the HIF system. Nat Med 9: 677-684, 2003.

20. Krishnamachary B, Berg-Dixon S, Kelly B, Agani F, Feldser D, Ferreira G, Iyer N, LaRusch J, Pak B, Taghavi P and Semenza GL: Regulation of colon carcinoma cell invasion by hypoxia-inducible factor 1. Cancer Res 63: 1138-1143, 2003.

21. Zhong H, De Marzo AM, Laughner E, Lim M, Hilton DA, Zagzag D, Buechler P, Isaacs WB, Semenza GL and Simons JW: Overexpression of hypoxia-inducible factor 1alpha in common human cancers and their metastases. Cancer Res 59: 5830-5835, 1999. 
22. Mariani F, Sena P, Marzona L, Riccio M, Fano R, Manni P, Gregorio CD, Pezzi A, Leon MP, Monni S, et al: Cyclooxygenase-2 and Hypoxia-Inducible Factor-1alpha protein expression is related to inflammation, and up-regulated since the early steps of colorectal carcinogenesis. Cancer Lett 279: 221-229, 2009.

23. Fransén K, Fenech M, Fredrikson M, Dabrosin C and Söderkvist P: Association between ulcerative growth and hypoxia inducible factor-1alpha polymorphisms in colorectal cancer patients. Mol Carcinog 45: 833-840, 2006.

24. Neufert C, Becker C and Neurath MF: An inducible mouse model of colon carcinogenesis for the analysis of sporadic and inflammation-driven tumor progression. Nat Protoc 2: 1998-2004, 2007.

25. Yuan L, Han J, Meng Q, Xi Q, Zhuang Q, Jiang Y, Han Y, Zhang B, Fang J and Wu G: Muscle-specific E3 ubiquitin ligases are involved in muscle atrophy of cancer cachexia: An in vitro and in vivo study. Oncol Rep 33: 2261-2268, 2015.

26. Livak KJ and Schmittgen TD: Analysis of relative gene expression data using real-time quantitative PCR and the 2(-Delta Delta C(T)) Method. Methods 25: 402-408, 2001.

27. Grivennikov SI and Karin M: Inflammation and oncogenesis: A vicious connection. Curr Opin Genet Dev 20: 65-71, 2010.

28. Suzuki R, Kohno H, Sugie S, Nakagama H and Tanaka T: Strain differences in the susceptibility to azoxymethane and dextran sodium sulfate-induced colon carcinogenesis in mice. Carcinogenesis 27: 162-169, 2006.

29. Becker C, Fantini MC, Schramm C, Lehr HA, Wirtz S, Nikolaev A, Burg J, Strand S, Kiesslich R, Huber S, et al: TGF-beta suppresses tumor progression in colon cancer by inhibition of IL-6 trans-signaling. Immunity 21: 491-501, 2004

30. Middleton K, Jones J, Lwin Z and Coward JI: Interleukin-6: An angiogenic target in solid tumours. Crit Rev Oncol Hematol 89: $129-139,2014$.

31. Bataille R, Barlogie B, Lu ZY, Rossi JF, Lavabre-Bertrand T, Beck T, Wijdenes J, Brochier J and Klein B: Biologic effects of anti-interleukin-6 murine monoclonal antibody in advanced multiple myeloma. Blood 86: 685-691, 1995.

32. Racadot E, Audhuy B, Duvernoy H, Thyss A, Lang JM, Wijdenes $\mathbf{J}$ and Hervé P: Clinical and immunological follow-up of patients with AIDS-associated Kaposi's sarcoma treated with an anti-IL-6 monoclonal antibody. Cytokines Mol Ther 1 133-138, 1995.
33. van Rhee F, Wong RS, Munshi N, Rossi JF, Ke XY, Fosså A, Simpson D, Capra M, Liu T, Hsieh RK, et al: Siltuximab for multicentric Castleman's disease: A randomised, double-blind, placebo-controlled trial. Lancet Oncol 15: 966-974, 2014.

34. Rossi JF, Négrier S, James ND, Kocak I, Hawkins R, Davis H, Prabhakar U, Qin X, Mulders P and Berns B: A phase I/II study of siltuximab (CNTO 328), an anti-interleukin-6 monoclonal antibody, in metastatic renal cell cancer. Br J Cancer 103: 1154-1162, 2010.

35. Fizazi K, De Bono JS, Flechon A, Heidenreich A, Voog E, Davis NB, Qi M, Bandekar R, Vermeulen JT, Cornfeld M and Hudes GR: Randomised phase II study of siltuximab (CNTO 328), an anti-IL-6 monoclonal antibody, in combination with mitoxantrone/prednisone versus mitoxantrone/prednisone alone in metastatic castration-resistant prostate cancer. Eur J Cancer 48: 85-93, 2012.

36. Angevin E, Tabernero J, Elez E, Cohen SJ, Bahleda R, van Laethem JL, Ottensmeier C, Lopez-Martin JA, Clive S, Joly F, et al: A phase I/II, multiple-dose, dose-escalation study of siltuximab, an anti-interleukin-6 monoclonal antibody, in patients with advanced solid tumors. Clin Cancer Res 20: 2192-2204, 2014.

37. Tanaka T, Narazaki M and Kishimoto T: Therapeutic targeting of the interleukin-6 receptor. Annu Rev Pharmacol Toxicol 52: 199-219, 2012

38. Grivennikov S, Karin E, Terzic J, Mucida D, Yu GY, Vallabhapurapu S, Scheller J, Rose-John S, Cheroutre H, Eckmann L and Karin M: IL-6 and Stat3 are required for survival of intestinal epithelial cells and development of colitis-associated cancer. Cancer Cell 15: 103-113, 2009

39. Bollrath J, Phesse TJ, von Burstin VA, Putoczki T, Bennecke M, Bateman T, Nebelsiek T, Lundgren-May T, Canli O, Schwitalla S, et al: gp130-mediated Stat 3 activation in enterocytes regulates cell survival and cell-cycle progression during colitis-associated tumorigenesis. Cancer Cell 15: 91-102, 2009.

40. Rigby RJ, Simmons JG, Greenhalgh CJ, Alexander WS and Lund PK: Suppressor of cytokine signaling 3 (SOCS3) limits damage-induced crypt hyper-proliferation and inflammation-associated tumorigenesis in the colon. Oncogene 26: 4833-4841, 2007.

41. Waldner MJ, Wirtz S, Jefremow A, Warntjen M, Neufert C, Atreya R, Becker C, Weigmann B, Vieth M, Rose-John S and Neurath MF: VEGF receptor signaling links inflammation and tumorigenesis in colitis-associated cancer. J Exp Med 207: 2855-2868, 2010 